\title{
The Effect of Self Assessment and Tax Knowledge on Tax Compliance
}

\author{
Asih Machfuzhoh ${ }^{1 *}$, Intan Puspanita ${ }^{2}$ \\ $1^{*, 2}$ University of Sultan Ageng Tirtayasa, Indonesia \\ Corresponding Author: asih.machfuzhoh@untirta.ac.id ${ }^{\left.1^{*}\right)}$
}

Keywords : Self assessment, tax knowledge, tax compliance

\begin{abstract}
:
Tax is the main income of the State. Unfortunately, citizens who fulfill their tax obligations are not balanced with the total population in Indonesia. This is a problem, how to increase tax compliance, to increase the tax ratio, so that income from taxes can be maximized. Many studies examine the factors that affect tax compliance. This research will examine the effect of self-assessment and tax knowledge on tax compliance of taxpayers. The sample of this study was 80 respondents, with the criteria of a private person in the city of Serang, who had a TIN and worked. The results of this study indicate that sels assessment and tax knowledge have a positive and significant impact on tax compliance, either partially or simultaneously.
\end{abstract}




\section{Introduction}

The largest state revenue comes from taxes and the rest comes from Non-Tax State Revenue (PNBP), this is proven in the State Revenue and Expenditure Budget (APBN). To trigger a high tax ratio in state revenues, there must be real efforts by the government to increase taxes, one of which is the ability to increase taxpayer compliance, so that the tax ratio is closely related to taxpayer compliance.

Wijaya (2016) said, the low compliance and lack of awareness of taxpayers is due to the fact that the Self Assessment System has not been placed as a philosophical foundation in fulfilling tax obligations. According to the Directorate General of Taxes, Law of the Republic of Indonesia Number 28 of 2007 concerning the Third Amendment to Law Number 6 of 1983 concerning General Provisions and Tax Procedures. RI State Institutions in 2007 No. 85 Along with the tax reform (tax reform) in 1983 which resulted in a fundamental change in the system and mechanism of tax collection from (official assessment system to self-assessment).

Self-assessment system is a tax collection system that gives trust and responsibility to taxpayers to calculate, deposit, and report the amount of tax owed themselves. In Indonesia, the self-assessment system has been implemented since 1984, but the level of taxpayer compliance in Indonesia is still lower than Malaysia, which has only implemented the self-assessment system since 2001. The trust given to the Self-Assessment System is still not considered a voluntary opportunity by taxpayers. The results of the research by Satyawati et al (2017) found that the application of the Self Assessment System had a significant effect on taxpayer compliance. Nurlaela (2017), which states that the self-assessment system has a significant positive effect on taxpayer compliance.

With the implementation of the Self Assessment System, it is expected that it will have a great influence on state revenues so that it is hoped that the voluntary efforts and active role of taxpayers in fulfilling their tax rights and obligations are expected. However, there are still weaknesses in this system, namely that there are still taxpayers who do not understand how to fulfill their tax obligations and even feel burdened because they have to fulfill their own tax obligations starting from registering themselves, filling out SPT (Statement Letters), calculating the amount of tax payable. and deposit their obligations so that taxpayers do not have the desire to comply in paying their taxes

According to Santoso (1990) self-assessment system can be successful if the taxpayers have high tax knowledge and discipline (tax conscousness). According to Palil (2010), the spirit of the self-assessment system is to educate taxpayers and make them care about their tax obligations Palil (2010) Therefore, taxpayers must have knowledge to understand tax regulations.

Knowledge of taxation is very important in implementing the self-assessment system. Knowledge of taxation is the basis for the implementation of the current system. Tax knowledge is closely related to taxpayer compliance. Taxpayers are said to have good tax knowledge if they 
have adequate knowledge in implementing the applicable system with no confusion in implementing the applicable system (paying, calculating and reporting).

The importance of taxpayers knowing knowledge about taxes is expected that taxpayers will know and understand the role of taxes as a source of state revenue that will be used to finance state expenditures that can provide welfare for the people. Without having knowledge of taxation, there is a tendency that taxpayers do not carry out their obligations to comply with tax regulations, either intentionally or unintentionally (Sucandra and Supadmi, 2016). Research conducted by Punarbhawa \& Aryani (2013) states that tax knowledge has a significant positive effect on the level of taxpayer compliance

The formulation of the problem in this study is related to the effect of self-assessment and knowledge of taxation on taxpayer compliance, namely: Does the application of self-assessment system and knowledge of taxation affect personal taxpayer compliance? This study aims to examine the effect of applying a self-assessment system and tax knowledge on individual taxpayer compliance.

\section{Research Method}

Research design

In this study, we will analyze the effect of applying the self-assessment system and tax knowledge on individual taxpayer compliance. The research design in this study begins with the frequent occurrence of compliance violations from taxpayers, ranging from not paying taxes owed, tax evasion, to reporting incorrect notification letters, especially the tax collection system implemented in Indonesia has shifted to a Self Assessment System. In collecting the selfassessment tax system, taxpayer awareness is something that needs to be considered in an effort to improve the implementation of the self-assessment system, thereby increasing taxpayer compliance. Tax awareness is a condition where the taxpayer knows or understands about taxes. Taxpayer awareness and compliance needs to be continuously grown, in order to realize the intention and willingness to fulfill the obligation to pay and report taxes in accordance with applicable regulations.

Vanesa and Priyono (2009) describe several forms of awareness of paying taxes that encourage taxpayers to pay taxes, namely first, awareness that taxes are a form of participation in supporting state development, by realizing this taxpayers want to pay taxes because they feel they are not disadvantaged from tax collection that done. According to Santoso Brotodihardjo (1990) self-assessment system can be successful if the taxpayers have high tax knowledge and discipline (tax conscousness). According to Palil (2010), the spirit of the self-assessment system is to educate taxpayers and make them care about their tax obligations (Palil, Moh. Risal, 2010). Therefore, taxpayers must have knowledge to understand tax regulations.

The location of this research was conducted in Serang, Banten with the criteria of individual taxpayers who work and have an NPWP. The analytical technique used in this study is 
descriptive statistics and hypothesis testing using regression analysis techniques. Regression analysis is used to examine the effect of applying self-assessment and tax knowledge on individual taxpayer compliance. In addition, the Classical Assumption Test is also carried out, a good regression model is a regression model that is free from multicollinearity, heteroscedasticity, and data normality problems. For this reason, it is necessary to test the regression model that will be used in the study.

Population and Research Sample

The population used in this study is an individual as a worker. The sampling technique used in this research is purposive sampling technique, namely the technique of determining the sample with certain considerations, where sample members will be selected in such a way that the sample formed can represent the characteristics of the population (Sugiyono, 2014). The criteria used as the basis for selecting the sample members in this study are individuals who have a TIN. The method of data collection was carried out by survey methods with data collection techniques through questionnaire techniques. Questionnaire technique is a data collection technique that is done by giving a set of questions and questions in writing to respondents to answer. The sample value of e is 0.5 with a result of 80 respondents.

Multiple Linear Regression Analysis

Multiple linear regression analysis is used to measure the strength of the relationship between two or more variables, also shows the direction of the relationship between the dependent variable and the independent variable. This test is to test the effect of several independent variables on the dependent variable. This study uses multiple linear regression because it has one dependent variable and more than independent variables (Ghozali, 2013). The regression equation in this study is for tax compliance as the dependent variable $(\mathrm{Y})$ with selfassessment (X1) and tax knowledge (X2) as the independent variables.

\section{Result and Discussion}

Research result

The data used in this study is primary data. Primary data was obtained by distributing questionnaires to taxpayers in Serang-Banten. Questionnaires related to self-assessment variables, tax knowledge and tax compliance. The sample in this study amounted to 80 respondents. Characteristics of respondents analyzed in this study include gender, age and last education.

Based on the results of the study, the characteristics of taxpayer respondents based on gender are presented in table 1 below: Based on table 1, it can be seen that respondents with male sex were 33 respondents (41.2\%) and respondents with female sex were 47 respondents (58.8\%). 
Table 1. Characteristics of Respondents by Gender

\begin{tabular}{ccc}
\hline Gender & Frekuensi & Persentase \\
\hline Female & 47 & 58,8 \\
Man & 33 & 41,2 \\
\hline Total & 80 & $100 \%$ \\
\hline
\end{tabular}

Source: Primary Data Results, 2021(Processed)

Characteristics of Respondents Based on Age Variations in the age of taxpayers, it will allow respondents to also vary by age. Respondent data by age can be seen in table 2 below. Based on table 2, it can be seen that most of the taxpayers aged between 30-40 years amounted to 41 people or (51.2\%) of 80 respondents. There are 10 taxpayers who are under 30 years old or (12.5\%), 29 people over 40 years old or (36.25\%) of the total respondents.

Table 2. Characteristics of Respondents by Age

\begin{tabular}{lll}
\hline Age & Frekuensi & Persentase \\
\hline$<30$ years & 10 & 12,5 \\
$30-40$ years & 41 & 51,2 \\
$>40$ years & 29 & 36,3 \\
\hline Total & 80 & $100 \%$ \\
\hline Source: Primary Data Results, 2021(Processed)
\end{tabular}

Tax compliance can be affected by education level. The higher a person's education, the higher the mindset that can affect tax compliance. So that in this study a description based on the level of education is important to know. The following is a description by level of education. Based on table 3, it can be seen that the education level of most taxpayers with S2 education is 40 people or (49.9\%) of 80 employee respondents, followed by 27 people or $(33.8 \%)$.

Table 3. Characteristics of Respondents Based on Education

\begin{tabular}{lll}
\hline Based on Education & Frekuensi & Persentase \\
\hline S2 & 40 & 50 \\
S1 & 27 & 33,7 \\
D3 & 7 & 8,8 \\
S3 & 6 & 7,5 \\
\hline Total & 80 & $100 \%$ \\
\hline Source: Primary Data Results, 2021(Processed)
\end{tabular}

Source: Primary Data Results, 2021(Processed)

\section{Data Analysis Multiple Linear Regression Analysis}

Multiple linear regression analysis was used to analyze the effect of the independent variables (self assessment and tax knowledge) on the dependent variable, namely tax compliance. The data was statistically processed for analysis and hypothesis testing using SPSS version 25 for Windows. 
Based on testing using SPSS version 25 for Windows, the results of multiple linear regression equations can be seen in table 4 below: For equation $Y$ from this study, it can be seen from the Unstandardized Coefficient B column. The results of data processing using SPSS 25 For Windows show that:

$$
Y=79,212+0,413 \times 1+0,741 \times 2+e
$$

Based on table 6, it can be described as follows: The self-assessment regression coefficient $(\mathrm{X} 1)$ is $\mathbf{0 . 4 1 3}$. This shows that this variable has a positive and significant effect on tax compliance or in other words, if the $\mathrm{X} 1$ variable is increased by one unit assuming other variables are constant, then tax compliance will increase by 0.413 . Tax knowledge regression coefficient (X2) is 0.741 . This shows that this variable has a positive and significant effect on tax compliance, or in other words, if the $\mathrm{X} 2$ variable is increased by one unit assuming other variables are constant, then tax compliance will increase by 0.741 .

Table 6. Regression Equation

\begin{tabular}{|c|c|c|c|c|c|c|}
\hline \multirow[b]{3}{*}{ Model } & & \multirow{2}{*}{\multicolumn{2}{|c|}{ Unstandardized Coefficients }} & \multirow{2}{*}{\multicolumn{2}{|c|}{ Standardized Coefficients }} & \multirow[b]{3}{*}{ Sig. } \\
\hline & & & & & & \\
\hline & & $B$ & Std. Error & Beta & $\mathrm{T}$ & \\
\hline \multirow[t]{3}{*}{1} & (Constant) & 79.212 & 6.507 & & 12.173 & .000 \\
\hline & $\begin{array}{l}\text { Self Assesment } \\
\text { (X1) }\end{array}$ & .413 & .124 & .306 & 3.318 & .001 \\
\hline & $\begin{array}{l}\text { Tax Knowledge } \\
\text { (X2) }\end{array}$ & .741 & .140 & .489 & 5.292 & .000 \\
\hline
\end{tabular}

Classic assumption test

Normality test

The normality test aims to determine whether the analyzed data is in the form or has a normal distribution or not. The steps taken in this test is to use the Normal Probability Plot. If the data distribution is normal, then the data distribution will be around the diagonal line and follow the direction of the diagonal line. 


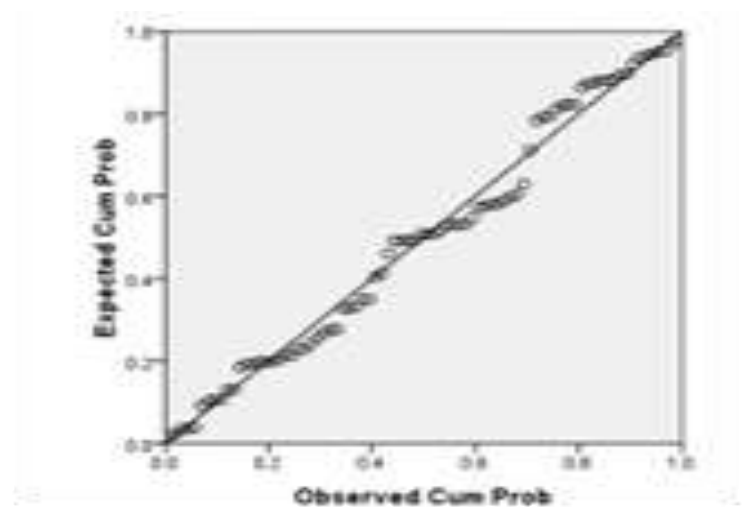

Source: Primary Data Results, 2021 (Processed)

Figure 1. P-P Plot Normality Test (Dependent Variable: Tax Compliance Y)

In the $p-p$ plot, it can be seen that the points spread around the diagonal line and tend to follow the direction of the diagonal line. Thus, the regression model meets the assumption of normality for this study.

\section{Goodness of Fit Test}

Coefficient of Determination (R2)

The magnitude of the contribution of the independent variable affecting the dependent variable can be seen from the value of the coefficient of determination. The value of the coefficient of determination or R2 can be seen in the results of data processing using SPSS 25 for windows in the Model Summary table for the R Square column as follows:

Table 7. Coefficient of Determination

\begin{tabular}{|c|c|c|c|c|c|}
\hline Model & $\mathrm{R}$ & R Square & Adjusted R Square & $\begin{array}{l}\text { Std. } \\
\text { Estin }\end{array}$ & $\begin{array}{l}\text { Error } \\
\text { the } \\
\text { te }\end{array}$ \\
\hline 1 & $.586 a$ & .344 & .327 & 4.26 & \\
\hline
\end{tabular}

From table 7 it can be seen that the resulting $\mathrm{R}$ number is 0.586 . This shows that the correlation or relationship between tax compliance (dependent variable) and the value of the independent variables (self-assessment variable and tax knowledge) is moderate. The coefficient of determination or R2 produced is $0.344 \%$. The adjusted R square value is $0.327 \%$. This means that $34.4 \%$ of the variation in tax compliance can be explained by the two independent variables used in the regression equation. While the rest is $65.6 \%(100 \%-34.4 \%)$ can be explained or predicted by other variables outside the two variables used in this study. 
Simultaneous (F-Test)

This test is carried out to see together the effect or significant positive relationship of the independent variable, namely self-assessment (X1) and tax knowledge (X2) on the dependent variable, namely tax compliance $(\mathrm{Y})$.

Table 8. Simultaneous Test (F-Test)

\begin{tabular}{|c|c|c|c|c|c|}
\hline Model & Sum of Squares & $\mathrm{Df}$ & Mean Square & $\mathrm{F}$ & Sig. \\
\hline Regression & 735.229 & 2 & 367.615 & 20.179 & $.000 a$ \\
\hline Residual & 1402.758 & 77 & 18.218 & & \\
\hline Total & 2137.988 & 79 & & & \\
\hline
\end{tabular}

Predictors: Predictors: (Constant), Self Assesment (X1), Tax Knowledge (X2)

Dependent Variable: Tax Compliance $Y$

Source: Primary Data Results, 2021 (Processed)

Based on table 8 shows that the value of Fcount (20.179) > Ftable with a significance level of $0.000<0.05$. This shows that the independent variable, namely Self Assessment (X1) and Tax Knowledge (X2) jointly and significantly affects the dependent variable, namely tax compliance (Y). The results of this study indicate that self-assessment and tax knowledge simultaneously (simultaneously) affect tax compliance which can be seen from the regression coefficient value of each independent variable having a positive sign, the results of hypothesis testing from the $F$ test show Fcount of 20,179 with a significance level of 0.000 which is less than 0.005 . This shows a unidirectional relationship between self-assessment variables (X1) and tax knowledge (X2) and tax compliance $(\mathrm{Y})$.

\section{Partial Test (t-test)}

The t-test was conducted to determine whether the independent variable consists of the self-assessment variable (X1) and tax knowledge (X2) partially or individually has an influence on the dependent variable, namely tax compliance $(\mathrm{Y})$.

Table 9. Partial Test (t-test)

\begin{tabular}{|c|c|c|c|c|c|c|}
\hline \multirow{3}{*}{\multicolumn{2}{|c|}{ Model }} & & \multicolumn{4}{|c|}{ Standardized Coefficients } \\
\hline & & \multicolumn{3}{|c|}{ Unstandardized Coefficients } & \multirow[b]{2}{*}{$\mathrm{T}$} & \multirow[b]{2}{*}{ Sig. } \\
\hline & & $B$ & Std. Error & Beta & & \\
\hline \multirow[t]{3}{*}{1} & (Constant) & 79.212 & 6.507 & & 12.173 & .000 \\
\hline & Self Assesm & .413 & .124 & .306 & 3.318 & .001 \\
\hline & Tax Knowle & .741 & .140 & .489 & 5.292 & .000 \\
\hline
\end{tabular}


Based on table.9 Partial Test, it can be seen that: The self-assessment variable with t count $>$ from $t$ table or $3.318>1.990$, then $\mathrm{HO}$ is rejected and $\mathrm{H} 1$ is accepted (research hypothesis), meaning that self-assessment has a significant effect on tax compliance. The test results show that the self-assessment variable (X1) has a tcount of 3.318 with a significance level of 0.001 . Because the probability $(0.001)$ is smaller than 0.05 , the regression coefficient of the elf assessment $(\mathrm{X} 1)$ has a significant effect on tax compliance $(\mathrm{Y})$.

The self-assessment variable is a variable that has an influence on tax compliance, this can be seen directly from the encouragement of taxpayers to carry out their tax obligations in accordance with applicable regulations, thereby automatically causing increased tax compliance.

Tax knowledge variable with $\mathrm{t}$ arithmetic $>$ from $\mathrm{t}$ table or $5,292>1,990$ then $\mathrm{H} 0$ is rejected and $\mathrm{H} 1$ is accepted (research hypothesis), meaning that tax knowledge has a significant effect on tax compliance. The test results show that the tax knowledge variable (X2) has a tcount of 5.292 with a significance level of 0.000 . Because the significance $(0.000)$ is smaller than 0.05 , the regression coefficient of tax knowledge (X2) has a significant effect on tax compliance (Y). Based on the results of the t-test test, tax knowledge makes a large contribution with a significance level of 0.000 less than 0.05 compared to self-assessment with a significance level of 0.001 less than 0.05. Of the two independent variables tested individually, the most dominant in influencing tax compliance is tax knowledge (with a coefficient of 0.489 ). This shows that tax knowledge is the most important variable in determining tax compliance of taxpayers. With tax knowledge possessed by taxpayers, taxpayers can fulfill their obligations as taxpayers properly and voluntarily. The next variable that has a significant role in influencing tax compliance in this study is self-assessment (with a coefficient of 0.306 ). All independent variables in this study have a positive effect on tax compliance.

\section{Conclusion}

Self-Assessment is categorized as quite good with the average value for all respondents' responses regarding the self-assessment system that has been running quite well. Based on the analysis of respondents' responses, the overall self-assessment system is included in the fairly good category, meaning that the self-assessment system carried out is in accordance with standard tax procedures.

Taxpayer compliance obtained an average score for all individual taxpayer compliance responses included in the fairly good category, thus it can be interpreted that individual taxpayer compliance has been running quite well. Based on the analysis of the responses of the overall respondents regarding WP OP Compliance, it falls into the fairly good category. This means that the compliance of taxpayers to fulfill their tax obligations is said to be quite good.

The effect of self-assessment on individual taxpayer compliance shows that there is a positive influence between self-assessment on individual taxpayer compliance, so that each 
increase in self-assessment will increase by 0.413 . So the higher the self-assessment, the higher the compliance of individual taxpayers.

The effect of tax knowledge on individual taxpayer compliance shows that there is a positive influence between tax knowledge on individual taxpayer compliance, so that every increase in tax knowledge will increase by 0.413 . So the increase in tax knowledge, the greater the compliance of individual taxpayers.

Of the two independent variables tested individually, the most dominant in influencing tax compliance is tax knowledge (with a coefficient of 0.489). This shows that tax knowledge is the most important variable in determining tax compliance of taxpayers. With tax knowledge possessed by taxpayers, taxpayers can fulfill their obligations as taxpayers properly and voluntarily.

\section{Suggestion}

In order to improve the system that has been running, the authors suggest the Pratama Tax Service Office in Serang to carry out counseling and tax consulting services to the public. By providing services and counseling regarding taxation procedures and managing tax documents, it is hoped that it can motivate the public to register with the KPP and the public can better understand the importance of taxation.

In order to improve individual taxpayer compliance, it is recommended for the Director at the General of Taxes provides direction to taxpayers so that taxpayers feel helped and find it easy to do their tax calculations. Because if the knowledge of the taxpayer is good, his tax rights and obligations will be good and he will be more obedient in his tax obligations.

In order to increase the influence of the self-assessment system on individual taxpayer compliance, it is recommended that taxpayers are expected to increase awareness of their tax rights and obligations in order to support government programs which the government will provide feedback to the public. Taxpayers who are less familiar with tax procedures can ask the tax officer or look through print or electronic media so that a more detailed explanation can be given.

\section{References}

Direktorat Jenderal Pajak. 2007. Undang-Undang Republik Indonesia Nomor 28 Tahun 2007 tentang Perubahan Ketiga atas Undang-Undang Nomor 6 Tahun 1983 tentang Ketentuan Umum dan Tata Cara Perpajakan. Lembaga Negara RI Tahun 2007 No. 85. Jakarta.

Endang Satyawati, Mardanung Patmo Cahjono 2017. Pengaruh Self Assessment System dan Sistem Informasi Perpajakan terhadap Kepatuhan Wajib Pajak, JRAK, 13(35).

Ghozali, I. 2018. Aplikasi Analisis Multivariate dengan Program IBM SPSS 25. Badan Penerbit Universitas Diponegoro. Semarang. 
Nurlaela, L. (2017) 'Pengaruh Self Assessment System dan Kualitas Pelayanan Pajak terhadap Kepatuhan Wajib Pajak Di KPP Pratama Garut', Jurnal Wacana Ekonomi, 16(3), pp. 001008

Palil, Moh. Rizal, Phd. 2010. Tax Knowledge and Tax Compliance Determinants In Self Assessment System In Malaysia. Departement of Accounting and Finance Birmingham Business School, The University of Birmingham. http://etheses.bham.ac.uk

Punarbhawa, I. G. A. B. and Aryani, N. K. L. (2013) 'Pengaruh Reformasi Administrasi Perpajakan dan Pengetahuan Perpajakan terhadap Tingkat Kepatuhan Pengusaha Kena Pajak (PKP)', E-Jurnal Akuntansi Universitas Udayana, 5(2), pp. 381-397

Santoso Brotodihardjo, R.SH, 1990. Pengantar Ilmu Hukum Pajak. PT Eresco, Bandung.

Sucandra, L. K. I. P. and Supadmi, N. L. (2016) 'Pengaruh Kualitas Pelayanan, Pemeriksaan Pajak, Pengetahuan Perpajakan dan Sanksi Perpajakan Pada Kepatuhan Wajib Pajak Restoran', E-Jurnal Akuntansi Universitas Udayana, 16(2), pp. 1210-1237

Sugiyono. 2017. Metode Penelitian Kuantitatif, Kualitatif, dan R\&D. CV Alfabeta. Bandung

Vanessa, Tatiana dan Priyono Hari Adi. 2009. Dampak Sunset Policy Terhadap FaktorFaktor Yang Mempengaruhi Kemauan Membayar Pajak; Sinopsium Nasional Perpajakan I. pp 1-8

Wijaya, E. (2016). Ada Pajak dalam Hubungan antara Masyarakat dan Pemerintah: http://www.pajak.go.id/content/article/ada-pajak-dalam-hubungan-antara-masyarakat danpemerintah 